\title{
Holistic competency development and the significance of learning domains in audiovisual archiving education
}

\author{
Karen F. Gracy \\ School of Information, Kent State University, P.O. Box 5190, Kent 44242, OH, USA \\ Tel.: +1 330672 0049; Fax: +1 330672 7965; E-mail: kgracy@kent.edu
}

\begin{abstract}
Audiovisual archiving education programs prepare individuals to care for film, video, and digital media collections found in cultural heritage institutions, such as libraries, archives, and museums. These programs combine traditional graduate education with significant experiential components to train students for work with moving images and sound material in archival and museum settings. Audiovisual archivist training requires a three-pronged approach that combines competencies drawn from the cognitive, affective, and psychomotor learning domains, blending conceptual, historical, and theoretical knowledge and soft skills such as communication and project management with training in hand and other sensory skills. Audiovisual education programs tend to be less explicit about requirements in expert handling and repair work (often referred to in the conservation profession as "hand skills"), sensory skills, and soft skills, however. While cognitive competencies are often stated directly through program documents such as course descriptions and syllabi, psychomotor and affective competencies tend to not be directly stated or are deprioritized in favor of development of cognitive competencies. This perceived gap establishes the need for making affective and psychomotor educational objectives more explicit in program curricula and requirements. In particular, learning objectives in the psychomotor domain have been neglected, which is problematic for a field that requires professionals to possess significant manual dexterity and sensory skills. This paper also makes the case for the design of a field-wide competency framework that accurately reflects the roles of the three learning domains and makes them equally essential for professional preparation in the audiovisual archiving profession.
\end{abstract}

Keywords: Audiovisual archiving education, domains of learning, cognitive learning, affective learning, psychomotor learning

\section{Introduction}

Over the last century, various information fields have strived to establish themselves as professions, specifically librarianship, information science, archival science and records management, and museum practice. Via the establishment of a body of theoretical and professional literature, educational programs, professional organizations, professional codes of ethics, and other means, these fields are generally recognized as being the loci for particular areas of expertise, with their practitioners recognized as such. Additionally, such work has become increasingly specialized, with separate controlling bodies (i.e., professional associations) to manage the entry of individuals into a particular specialty. Such is the story of audiovisual archiving, which is an area of expertise arising from the conjunction of several allied fields including archives, librarianship, conservation, and media studies. Figure 1 provides a 


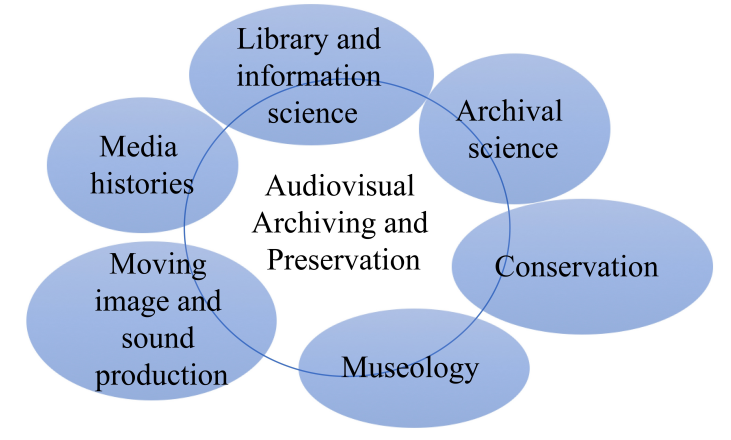

Fig. 1. Influences of LIS and allied fields on audiovisual archiving education.

representation of the various fields influencing the (AV) audiovisual archiving profession.

Thus far, AV archiving has emerged from a bricolage approach, which borrows theory, knowledge, and skills from a variety of sources where they are useful in their application to the work at hand. Principles of preservation in audiovisual archiving owe a great debt to conservation, cataloging and documentation to librarianship and information science, and exhibition to museum studies. There is also a strong artisanal influence, due to the specialized nature of preservation and restoration work.

The process of professionalization has nudged audiovisual archiving, along with many of the other information fields, from the apprenticeship model of education to a more standardized model that gives preference to university-based accredited degrees and professional certification [1-3]. That transition resulted in fields favoring the systematic transfer of knowledge, common ethical beliefs, scientific principles, intellectual rigor, and modern technologies over the transfer of professional expertise from masters to students. Professional associations play a key role in the development of standardized educational requirements, which can take the form of accredited programs (as is the case for the MLIS degree in North America $[4,5]$ ), or certification of individuals via professional associations, governmental entities, or independent bodies (e.g., records managers and archivists [3,6,7]).

An important development related to the control of knowledge via accreditation or certification is the establishment of competencies or educational guidelines to guide the development of educational programs. While such competencies or guidelines are not binding, in the sense that there is a legal obligation for them to be followed for programs to achieve accreditation, or for individuals to earn certification in a particular field, they do influence educational programs in that they are often viewed as the consensus recommendation of the profession as to what constitutes essential knowledge and skills for practitioners. Educational guidelines thus hold significant weight in shaping discourse about how the profession defines itself, what values it embodies, and what constitutes its unique expertise. 
This paper looks specifically at the current status of educational guidelines for the evolving field of audiovisual archiving, which is youthful in comparison to other information fields. While there have been several attempts to bring about standardization of the field's knowledge base and educational/experiential requirements for becoming a recognized practitioner, primarily via the path of credentialing, thus far these efforts have been unsuccessful [2].

Why have these efforts not succeeded? One explanation may be that the field has not sufficiently or transparently defined its knowledge base, which makes it difficult to establish the boundaries of the field. This paper suggests that the processes of generating competencies and developing an overarching competency framework are instrumental in exposing the scope and variety of needed knowledge and skills. The field of audiovisual archiving needs to further explore and explicate the types of work in which such practitioners engage in order to create a set of guidelines or competencies that would be acceptable to the field and useful for education providers.

These processes of competency development and establishment of a hierarchy should include investigations into the three domains of learning - cognitive, affective, and psychomotor - from which educators draw to design curricula, learning objectives/outcomes, and learning activities. As will be shown through this paper, the psychomotor domain is particularly fertile ground for generating competencies that are relevant for the audiovisual archiving field.

\section{Professionalization in the information professions}

The following section briefly sketches the history of professionalization via accreditation and/or certification of individuals in two information fields, specifically librarianship and archival studies, for the purpose of comparing their development to that of audiovisual archiving. While the information disciplines encompass a number of fields [8], librarianship and archival studies were selected for comparative purposes because of their influence on $\mathrm{AV}$ archiving education. Other related fields, such as museum studies and conservation, may also be helpful case studies to consider. Also, it is worth noting that this paper focuses on professional development in North America and thus readers are referred to other sources for the history of information professionalization outside of this context.

\subsection{Librarianship}

Scholars such as Williamson [9], Asheim [10], Winter [5], and Abbott [11] have studied efforts to professionalize the information fields extensively. Abbott articulated several criteria by which a field can be described as a profession [11], including: 1) having a common body of knowledge and skills; 2) a formal system of education and training; 3) a code of professional ethics; 4) a professional association; 5) legal recognition; and, 6) a service orientation. Abbott characterized librarianship as a 
semi-profession because while it meets most of the above criteria, it does not have the legal recognition that would allow the profession to strictly control membership in the profession. Library technicians and other paraprofessionals often perform tasks that might be considered as the domain of the professional librarian. Despite these concerns, widespread recognition of the American Library Association-accredited MLIS degree as the accepted professional credential in North America means many positions in the United States and Canada are reserved for those practitioners with the MLIS.

\subsection{Archival science}

Archival studies programs in North America can be found as a specialty in either MLIS programs or public history programs. While early programs tended to be established within public history programs, by the 1980s archival specializations had been launched within several MLIS programs, with significant growth since that time in the number of archival faculty and the number of archives courses offered in LIS programs [1]. This shift from history to LIS programs is often attributed to the greater level of commitment in LIS programs, in terms of growing the curriculum and number of faculty [12]. Archival studies also benefitted from its positioning within the larger information professions, which encourages a broader preparation for students in areas such as information organization and technology.

In addition to the established educational programs, the archives profession in the United States currently has two professional organizations with interests in the preparation of archival professionals: the Society of American Archivists (SAA) and the Academy of Certified Archivists (ACA). SAA has been involved in the development of educational guidelines since the 1970s; the most recent iteration of its guidelines was revised in 2016 [6]. It does not engage in certification of individuals or accreditation of archival studies programs, due to the costs involved, and concerns by the field about creating guidelines that would unfairly exclude certain programs found primarily within public history departments (which may not be able to offer the same depth in their curriculum as other archival programs found in information schools).

There is, however, an organization that does certify individuals as archival professionals. The ACA, established in 1989, is the certifying body for the archives profession in the United States. It offers the credential of Certified Archivist to practitioners, which is earned via successful passing of an examination and providing proof of work experience in the field. The number of archivists who are current members of the ACA (thus holding the title of Certified Archivist) was approximately 1,200 in 2014 [3]; when comparing this number to the total number of archivists in the United States (31,000, according to the USA Bureau of Labor Statistics), this would indicate that less than 4 percent of archivists earn certification. A study of job advertisements by Hamburger in 2014 showed that few employers require certification for employment [13]. Thus, one can safely assume that the credential is not universally 
embraced by the archival profession in the same way that the MLIS degree has been by the library profession.

Difficulties of systematizing educational preparation of archivists via accreditation or certification of individuals have resulted in little progress toward a field-wide standard that governs who may practice in the archive profession. There are still many individuals who affiliate with the archives profession that have little to no formal training, relying largely on practical experience. A dozen years ago, the Society of American Archivists performed a census of archivists in the United States that indicated $35 \%$ of archivists surveyed had gone to graduate school as their primary source of archival training or education. Almost 20\% indicated that they had relied on continuing education, $21 \%$ had self-educated, and just over $23 \%$ answered "other" [14]. While it would be interesting to have an update on this data, the educational landscape has not changed considerably in the last ten years, with the exception of increasing availability of online continuing education opportunities (which would suggest that the number of practitioners relying on continuing education may have actually increased). SAA itself has introduced two certificate programs to its continuing education offerings (Digital Archives Specialist Certificate, and the Arrangement and Description Certificate), a move which appears to indicate recognition that many archivists are interested in acquiring knowledge in these particular key areas and are bypassing more formal educational programs for those offered in a continuing education setting.

\subsection{Audiovisual archiving}

In the field of audiovisual archiving, professionalization has followed a somewhat different path than librarianship and archival studies. These differences may be traced to the influences of a variety of stakeholders not common in the other information fields. The AV archiving field has its historical origins in four communities of practice - the first community was made up of passionate connoisseurs of moving images and sound recordings, the second community arose from scholars and institutions interested in the media itself as cultural objects of value, the third community includes the artists or scholars who use audiovisual media to create original works or record cultural or scientific phenomena, and a fourth community, rooted in commercial endeavors, with a financial stake in the preservation and archiving of their products (i.e., films, television programs, sound recordings, etc.).

Devoted film fans and collectors, such as Henri Langlois (founder of the Cinémathèque Française), typify the early audiovisual archivists; these individuals were often focused on collecting and showing or playing materials above all other activities. Institutions like the Museum of Modern Art in New York and the Library of Congress, and the scholars interested in studying audiovisual materials as cultural objects, make up the second type of archivist. They often prioritize conservation of materials over other activities, however, the availability of digital reformatting, restoration, and distribution technologies has started to shift the focus to access. 
Artists often create collections of audiovisual materials in order to preserve their own work or that of the community in which they are engaged; alternately, they may see such collections as sources of raw material from which to make new works. Last, the commercial entities that make up the moving image and sound media industries, such as motion picture production companies, distributors, and laboratory personnel also have a stake in audiovisual archiving; in their universe, media are assets and the point of maintaining collections is to be able to continue to monetize them through various outlets.

While international associations had existed for some time to support audiovisual archiving work of those working at national archives and libraries (e.g., the International Federation of Film Archives, founded in 1938, and the International Association of Sound and Audiovisual Archives, established in 1969), in time these communities would also come together and begin to formalize the profession through the establishment of member-driven professional associations such as the Visual Materials Section (created in 1951) and Recorded Sound Roundtable (formed in 1989) of the Society of American Archivists, the Association of Recorded Sound Collections (established in 1966), and the Association of Moving Image Archivists (founded in 1990). These organizations have been key loci for the presentation and dissemination of professional knowledge for the fields, and have increased the visibility of and respect for this specialized work. To date, however, these organizations have not yet created a formal set of recommendations for educational preparation or endorsed a list of competencies, which makes it difficult for the field to distinguish among individuals who purport to be audiovisual archivists but have varying degrees of preparation and experience.

\section{The importance of standardization of curricula and development of competencies in the information professions}

It is worthwhile to examine the role of education and standardized curricula in achieving the goals of professionalization for a field. As noted above in this study, Abbott identified a number of criteria for professionalization, the first two of which include having a common body of knowledge/skills, and a formal system of education and training. Both of these criteria rely heavily on systematic, rigorous review of the quality and efficacy of practices and practitioners by a recognized body of experts.

In the information professions over the last 30-40 years, the fields have made increasing attempts to create curricular guidelines for shaping educational programs at the national and international levels. These guidelines tend to be in the form of suggestions or recommendations, but can also take the form of more formalized competency frameworks such as the one compiled by OCLC's WebJunction for the library science field [15]. Recommendations tend to be more aspirational than mandatory in most cases, except for school librarian programs, which are usually governed by state 
licensure requirements as well as educational guidelines of the American Association of School Librarians. In the case of the American Library Association (ALA), their set of competences have a connection to its Standards for Accreditation, which are used as the primary document for evaluating the quality of MLIS degree programs in North America.

\subsection{The role of competency development in the information professions}

For decades, educators in the fields of archival studies, conservation, and library and information science have promoted the importance of educational guidelines or competencies for professional education and development as part of the attempt to establish a commonly-accepted body of knowledge for these professions and shape the curriculum of educational programs that generate new professionals. In the information professions, development of formal competencies became a pressing priority in the 1990s and early 2000s, as the introduction of new technologies to libraries and other information centers began to change significantly the type of tasks in which librarians were expected to be engaged. Information professionals were now required to quickly adapt to, adopt, and market new technologies such as electronic catalogs and various online information systems. They were also encouraged to develop more advanced and sophisticated "soft" skills such as communication, critical analysis, negotiation, and collaboration [16,17].

During this same time period the information professions became focused on the idea of having a set of core competencies for the profession. Giesecke and McNeil, writing about their experiences developing core competencies for library staff at the University of Nebraska - Lincoln, defined them as "the skills, knowledge, and personal attributes that contribute to an individual's success in a particular position" [18]. Each field within the larger set of information professions has taken a slightly different path to developing competencies or guidelines, based on that field's expectations and requirements. In 1991, the American Society of Information Science issued its brief Educational Guidelines statement, with a revised version issued by the association in 2001 (by then, the American Society for Information Science and Technology, and as of 2013, the Association for Information Science and Technology) [19]. ASIST has considered the possibility of accrediting information schools, a designation which would include MLIS-granting programs that are part of such schools, but it has not established a formal accrediting body at this time [20]. More recently, the American Library Association (ALA) issued its Core Competences of Librarianship in 2009 [21]. While these competences are not directly related to the ALA standards for reaccreditation of educational programs, many schools have found the competences useful as an indicator of how ALA defines the knowledge domain for the profession.

Another development was the recognition that certain specialties within the information professions may have unique competencies that are not common to the information professions as a whole. Thus, many professional organizations serving these 
specialties pursued the development of competencies for their respective areas. Some of the earliest guidelines in library science were produced by library associations focused on services to youth, including the Young Adult Library Services Association (YALSA) in 1981, the American Association of School Librarians (AASL) in 1989, and the Association for Library Service to Children (ALSC) in 1989 [22-24]. It is not surprising that the earliest competencies or guidelines emerged from those organizations concerned with youth services, as they tend to be heavily influenced by developments in the field of education. Educators in the late 1960s and 1970s had begun to focus on creating competency-based teacher education programs, and it is likely to have influenced librarians and library faculty seeking to shape educational programs in librarianship.

Many other library and archive associations eventually followed the lead of ASIST, ALA, and other ALA-affiliated organizations to support education of information professionals in specialized areas, including the following:

- Archivists [6,7]

- Art information professionals [25]

- Cataloging and metadata professionals [22]

- Electronic resources and serials management [26,27]

- Health sciences librarians [28]

- Law librarians [29]

- Library leaders/managers [30]

- Music librarians [31]

- Scholarly communication librarians [32]

- Special collections professionals [33]

- Special librarians [34]

- Visual resources management [35]

Another allied area worth noting is that of conservation. Conservation is a field that developed out of art history, other related cultural heritage fields, and scientific disciplines such as archaeology, historic preservation, and applied chemistry. Its unique blend of various humanities and scientific traditions means that educational preparation of conservators results in polymath professionals who are equally capable of conducting chemical tests to identify the composition of a material as they are in repairing structurally compromised objects that suffer from damage and deterioration. Bench work, i.e., experience in working with materials to diagnose, treat, and repair damage to items, is an essential part of their preparation, equal to the disciplinary knowledge that must also be acquired.

To provide guidance for those select programs that educate conservation practitioners, the American Institute for Conservation (AIC) has developed two competency frameworks: one for conservators and the second for conservation technicians (who often perform bench work but do not possess the background in chemistry and cultural heritage that conservators possess). The AIC's conservator competencies framework was published in 2003, and the competencies for technicians was 
issued in 2005 [36,37]. Conservation provides an important point of comparison for the suggested development of a competency framework for audiovisual archiving, a specialty currently lacking any sort of formal competency set or educational guidelines, because of the importance of hand skills in both fields. In that sense, it is a highly relevant model to consult.

\subsection{A brief history of audiovisual archiving education: The rocky road to standardization}

Audiovisual archiving education has trod many paths that point to convergence and consolidation of professional knowledge. Personnel in media archives have traditionally been split among several fields: 1) preservation technicians in media archives often had backgrounds in film or video production in the case of moving image archiving, or sound engineering, in the case of audio archiving; 2) curatorial and public access staff were more likely to have academic backgrounds in the history of media or art, or other associated humanities or social science disciplines relevant to the subject matter of the audiovisual material (e.g., anthropology for ethnographic film); and 3) staff dealing with the description and cataloging of materials often came from the information professions, specifically librarianship. Thus, prior to the creation of formal educational programs, audiovisual archivists came from a variety of backgrounds, sharing a common interest in media as cultural and historical objects, as well as being commercial assets. Several histories of audiovisual archives and the $\mathrm{AV}$ archiving profession have been published in the last thirty years, which provide significant detail on how the field emerged in the $20^{\text {th }}$ century as the need to preserve and ensure access to the world's audiovisual heritage became evident. Readers are referred to works by Slide [38], Houston [39], Gracy [40], and Frick [41] for more background information on the field's development.

Previous to the establishment of graduate-level programs in audiovisual archiving in the 1990s and 2000s, educational opportunities were limited to short courses offered by the International Federation of Film Archives (FIAF), the International Federation of Television Archives (FIAT), the International Association of Sound and Audiovisual Archives (IASA), as well as conference workshops offered by other professional associations such the Association of Moving Image Archivists, the Association of Recorded Sound Collections, the Society of American Archivists, and other national and international associations. For most audiovisual archivists working prior to the 1990's, education took place on-the-job, in the form of internships and apprenticeships. The introduction of graduate education options did not make these hands-on opportunities obsolete, however, as there continue to be many working professionals who do not have the time or resources to attend a multi-year university program. Short courses, internships, and volunteer opportunities still provide essential bridges for acquiring specialized skill sets and securing permanent employment in the field for many aspiring audiovisual archivists, particularly those who cannot access more formal programs due to geographical or financial limitations. 
This situation is similar to that of archival professionals working with records and manuscripts.

University-affiliated educational opportunities for audiovisual archiving have a relatively brief history in comparison to the development of library science and affiliated fields such as archival studies and museum studies. In the United States, the first formal educational program for audiovisual archiving was established just over twenty years ago in 1996 at the L. Jeffrey Selznick School for Film Preservation located at the George Eastman House (GEH) in Rochester, New York. The GEH program initially offered a certificate, but eventually it partnered with the University of Rochester to offer a master's degree option as well. The GEH program was soon followed by the first university-based graduate programs at the University of California, Los Angeles (2001) and the Tisch School for the Arts, New York University (2002). The first program in Canada is offered by Ryerson University in Toronto (a Master of Arts in Film + Photography Preservation and Collections Management). In the United Kingdom, Europe, Asia, and Australia, available programs include:

- a master's degree in Film Studies: Programming and Curation offered by the National Film and Television School in conjunction with the British Film Institute in the United Kingdom;

- bachelor's and master's programs at the Hochschule für Technik und Wirtschaft in Berlin;

- a master's program in Conservation of New Media and Digital Information at State Academy of Art and Design Stuttgart;

- a master's program in Heritage Studies: Preservation and Presentation of the Moving Image at the University of Amsterdam in The Netherlands in conjunction with the EYE Institute;

- a master's program in film studies with an archives emphasis at the University of Lausanne in Switzerland;

- a master's program in documentary studies and film archiving at Tainan National University, Taiwan, and,

- Charles Sturt University's online Graduate Certificate in Audiovisual Archiving (Wagga Wagga, New South Wales, Australia), offered in conjunction with the National Sound and Film Archive in Canberra.

It is worth noting that the programs listed above focus primarily on film and television/video preservation, with some limited coverage of audio preservation, specifically analog audio stored on magnetic media or digital audio on a variety of storage devices. At this time, there is no graduate program focusing exclusively on audio preservation, although some coursework in audio preservation is offered by the moving image archiving programs as well as a number of other universities in North America, including the University of Texas, Austin; the University of California, Los Angeles; Indiana University (Bloomington), University of Illinois (UrbanaChampaign); Simmons College (Boston, Massachusetts); Pratt Institute (New York City); Kent State University (Kent, Ohio); the University of British Columbia; and the University of Montréal. 
Experiential opportunities provide an essential supplement to academic programs and serve as a locus for learning soft skills such as working with people, and managing projects, as well as hand skills essential to handling and performing conservation tasks on materials. Such practical opportunities help to bridge the gap between the classroom and the archive for those interested in AV conservation..

While the field of audiovisual archiving does not have a formal set of educational guidelines developed by a professional association for either moving image or sound archiving, there have been several influential publications that have provided an outline for a suggested curriculum for educational programs. In 1990, UNESCO published Helen Harrison's Curriculum Development for Training of Personnel in Moving Image and Sound Archives [42]. Harrison clusters competencies by types of positions: top management, middle management, and skilled workers (technician/engineers). Top management includes heads of acquisition, cataloguing, documentation, technical services, library, publications, education/exhibition, public relations, and administration. All top management positions require extensive knowledge of the history of film, video, broadcasting, the technical processes and feasible audiovisual recording modes, as well as a thorough knowledge of general history. Middle managers may be division heads or specialist workers such as engineers/technicians. Skilled workers are support staff who may work in a variety of capacities to care for collections.

Harrison includes detailed descriptions of duties at each of these levels, which reflects the types of archives with which she was most familiar - national media archives that had broad responsibilities in terms of the scope of their collections and their mission, and that were organized in typical top-down hierarchies. Today, many organizations involved in audiovisual archiving activities would not have the same distinctions between management, technicians, and skilled workers, particularly those working in cultural heritage organizations where care of such collections is one responsibility among many goals and activities. In such organizations, many archivists would be independent or semi-autonomous in their day-to-day work activities with audiovisual collections. Audiovisual archivists may also be working in team-led organizations, where their expertise is combined with that of other personnel working in conservation/restoration laboratories, reformatting/digitization units, and digital initiatives, or in the case of commercial organizations, with people responsible for creating versions of material for sales and distribution in a variety of venues.

Ray Edmondson's Philosophy of AV Archiving, first published in 1998 and revised in 2004 and 2016 [43], is another seminal resource worth examining for insight into what audiovisual archivists do and what preparation they require. While Edmondson does not lay out a detailed set of educational guidelines, he does describe what could be considered high-level core competencies for audiovisual archivists:

There are broad areas of knowledge which could be considered as basic equipment for all audiovisual archivists, whether acquired formally or informally. These include: 
- The history of audiovisual media

- Knowledge of the recording technologies of various audiovisual media

- Collection management strategies and policies

- Technological basis for preservation and access

- The history of audiovisual archiving

- Basic media-related physics and chemistry

- An understanding of contemporary history

Edmondson's list of important background knowledge for archivists relies largely on cognitive competencies, however, and does not articulate skills and knowledge that might be categorized as soft skills or hand/sensory skills.

\section{Defining competencies and their role in professional education}

A competency can be defined as "the capability to apply or use a set of related knowledge, skills, and abilities required to successfully perform "critical work functions' or tasks in a defined work setting" [44]. A competency can be distinguished from a learning objective through the former's emphasis on application or use of knowledge to tasks in practical settings; it helps students connect knowledge acquired in an academic setting to the "real world". Competencies are particularly valuable tools for guiding the design of courses in professional programs, where students need to apply knowledge gained in the classroom to perform tasks, make decisions, and solve problems. Ideally, educators should be integrating opportunities to acquire and show competencies throughout a program, via coursework, practica and experiential opportunities, and social interactions with students, instructors, and working professionals.

Although one can trace the earliest notions of competency to the 1920s, when scientific management principles began to be introduced in the United States and elsewhere, many scholars point to the work of McClelland on testing for competency as the primary indicator of future success in a job or profession [45]. Over the next two decades, the idea of competencies as a guiding principle for design of professional programs began to appear. By the 1980s and 1990s, literature of the professions such as education [46], surgical medicine [47,48], nursing [49-52], and public health [53] began to emphasize the importance of students being able to practice and show competency in a wide range of professional activities.

\subsection{The importance of developing competencies for the information professions}

The point of developing competencies is simple. Learning competences help educators and students upon what students can do upon completion of a learning module, course, or program, not just on what they know. A well-written competency can provide concrete evidence that students and working professionals can apply what they 


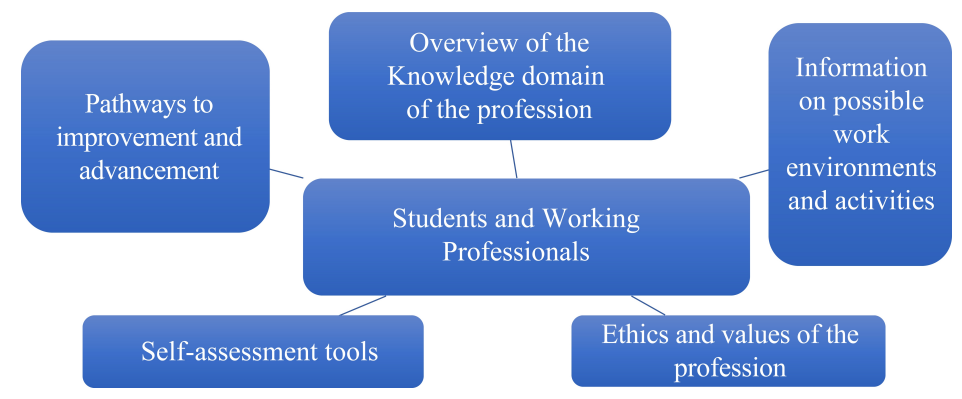

Fig. 2. Competency needs of audiovisual archiving students and working professionals.

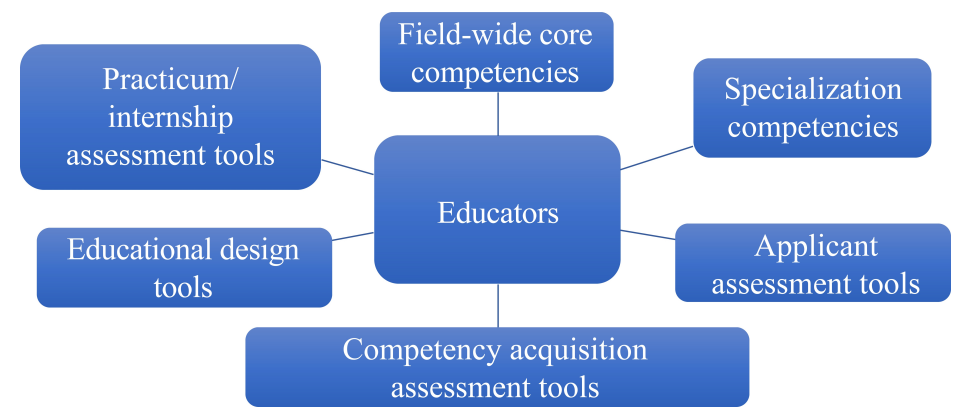

Fig. 3. Competency needs of audiovisual archiving educators.

know in a variety of settings, be able to analyze and evaluate new problems and situations, and create solutions that may integrate new tools and systems to improve the final outcome.

In human resources parlance, a "competency framework" is a structure that sets out and defines each individual competency (such as problem-solving or people management) required by individuals working in an organization. In educational settings, a competency framework takes the form of a structure to guide curriculum development and implementation for academic programs. While an individual educational program can establish its own competency framework, there is also value in building one that the field or profession endorses, often through a professional association.

To give one a sense of how competency frameworks benefit multiple stakeholders in a profession, the following illustrations (Figs 2-5) depict specific benefits for four different groups: students and working professionals; educators, employers, and professional associations/certifying bodies.

As one can see from these figures, a competency framework reflects the current knowledge base of the profession, and allows students, practitioners, employers, educators, and professional bodies to draw from the competencies in various educational and assessment activities - whether it be an educator preparing syllabi and learning materials for a course, an employer assessing job candidates on their preparation for 


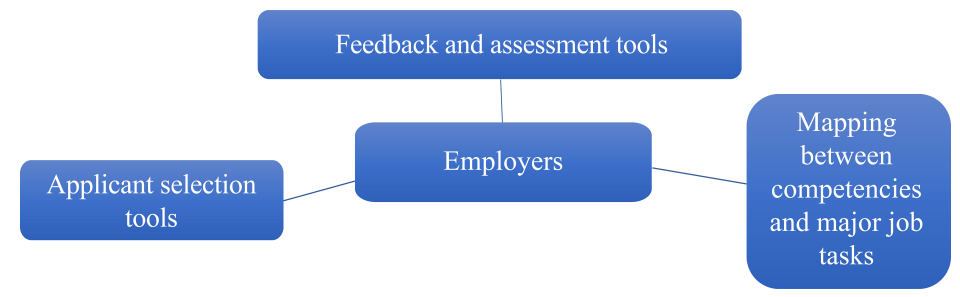

Fig. 4. Competency needs of employers in audiovisual archives.

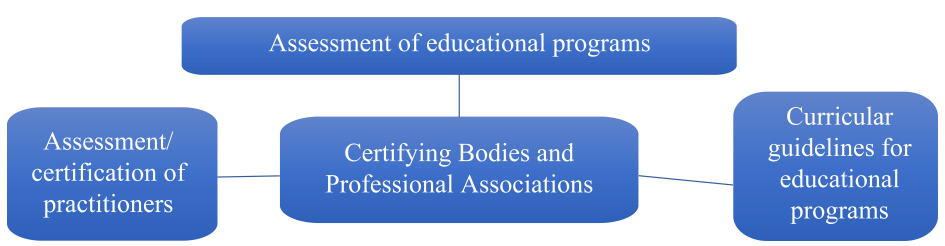

Fig. 5. Competency needs of certifying bodies and professional associations.

a position, students assessing themselves to identify gaps in their knowledge, or professional organizations creating standards for program accreditation or practitioner certification.

\subsection{Competency framework development}

The process of developing a competency framework for a particular educational program or a professional field, includes the following steps:

1. Preparation: defining the purpose of the framework and gathering a team to develop it. Contributors should include practitioners as well as educators and employers.

2. Data Collection: gathering information about relevant competencies through a variety of data collection techniques, including literature reviews, analysis of employment advertisements, surveys, observations, interviews, and focus groups.

3. Building the framework by grouping the competency statements into a logical hierarchy, creating and refining subgroups, and identifying and naming the competencies.

4. Implementing the framework by using it as the starting point for developing and revising courses or programs, relating course-specific learning objectives to program-wide competencies, creating job advertisements and assessing applicants, and practitioner self-assessment of skillsets and knowledge to identify gaps, etc.

There are a number of ways to generate and classify types of competencies; for example, one simple taxonomy categorizes them as professional, functional, jobspecific, or leadership-related. In tertiary educational settings educators tend to focus 
more on the first two of these categories to shape a program's curriculum. Professional competencies are generic, or core, competencies required of all professionals in a field, and can include core subject knowledge as well as behavioral, "soft" skills. Functional competencies relate to standards of performance needed by an individual working in a specific role or function and can be technical expertise or specialized knowledge. The other two categories are less likely to be integrated into an educational program but could be via activities that occur outside the classroom such as internships or practica, social activities, and problem-solving activities.

\subsection{Domains of learning (cognitive, affective, psychomotor)}

Another way of looking at competency development and grouping is to use the domains of learning model first defined by Bloom in 1956 [54]. Education researchers and practitioners often use Bloom's typology of learning domains to categorize learning objectives according to levels of complexity and specificity. At the top level of the hierarchy, Bloom defined three domains: cognitive (knowledge-based), affective (emotion-based), and psychomotor (action-based). The cognitive domain is the one with which tertiary educators are often most familiar and it is often the primary focus of tertiary education. Cognitive learning helps students acquire knowledge of a particular discipline or field, i.e., its theoretical constructs and historical contexts. The cognitive domain framework is used extensively in many fields to create learning objectives and outcomes for courses, match learning activities with objectives, and help educators scaffold learning from lower to higher level knowledge and skill acquisition. Table 1 summarizes the six levels of the cognitive domain; the levels were altered slightly in a 2001 revision of the taxonomy [55] and thus the revised version is featured in this table. Examples are drawn from the audiovisual archiving field to further explicate the levels:

The second domain of learning, the affective domain, includes those "soft" skills that educators, particularly those working in professional fields, are interested in cultivating. Examples of soft skills might include communication, project and task management, and teamwork. In Table 2, the levels of learning associated with the affective domain are presented; they represent increasingly sophisticated skills in emotional and social intelligence. It is worth emphasizing that the classroom should not be the only place where this learning occurs; there are many experiential activities such as internships, conferences, and social gatherings that can help students become more adept in communication, teamwork, collaboration, etc.

The final domain of learning, the psychomotor domain, is one that tends to be overlooked by many educators working at the college/university level; tertiary education environments often prefer to emphasize the first two domains, particularly cognitive learning, over all others. For certain fields or professions, however, the psychomotor domain is essential to students' education. This domain involves skills requiring physical movement, coordination, and/or use of the senses such as sight, hearing, smell, or touch. Any field or profession that requires students to use their senses to 
Table 1

Cognitive domain of Bloom's taxonomy (2001 revision, [55])

\begin{tabular}{|c|c|c|}
\hline Level & Definition (from Clark) [60] & Audiovisual archiving in situ examples \\
\hline Remember & $\begin{array}{l}\text { Recall or retrieve previous learned } \\
\text { information. }\end{array}$ & $\begin{array}{l}\text { - Recall the stages of deterioration of physical me- } \\
\text { dia. }\end{array}$ \\
\hline Understand & $\begin{array}{l}\text { Comprehending the meaning, tran- } \\
\text { slation, interpolation, and interpre- } \\
\text { tation of instructions and prob- } \\
\text { lems. State a problem in one's own } \\
\text { words. }\end{array}$ & $\begin{array}{l}\text { - Identify a particular stage of deterioration of an } \\
\text { object and make a recommendation for how to } \\
\text { care for it or reformat it. } \\
\text { - Read and interpret markings and physical charac- } \\
\text { teristics found on an audiovisual object, such as an } \\
\text { edge code on film stock or the width of a magnetic } \\
\text { tape to determine the format, age, composition, or } \\
\text { provenance of the base material. }\end{array}$ \\
\hline Apply & $\begin{array}{l}\text { Use a concept in a new situation } \\
\text { or unprompted use of an abstrac- } \\
\text { tion. Applies what was learned in } \\
\text { the classroom into novel situations } \\
\text { in the work place. }\end{array}$ & $\begin{array}{l}\text { - Assess the content and physical condition of a pre- } \\
\text { viously unexamined audiovisual item using tex- } \\
\text { tual, visual, auditory, and olfactory evidence and } \\
\text { create an inventory or database to capture this in- } \\
\text { formation for future use. }\end{array}$ \\
\hline Analyze & $\begin{array}{l}\text { Separates material or concepts into } \\
\text { component parts so that its orga- } \\
\text { nizational structure may be under- } \\
\text { stood. Distinguishes between facts } \\
\text { and inferences. }\end{array}$ & $\begin{array}{l}\text { - Assess a grouping of audiovisual materials to de- } \\
\text { termine each item's relationship to the others and } \\
\text { to the creator's activities. }\end{array}$ \\
\hline Evaluate & $\begin{array}{l}\text { Make judgments about the value of } \\
\text { ideas or materials. }\end{array}$ & $\begin{array}{l}\text { - Appraise the archival value of an audiovisual item } \\
\text { or collection of items. }\end{array}$ \\
\hline Create & $\begin{array}{l}\text { Builds a structure or pattern from } \\
\text { diverse elements. Put parts toge- } \\
\text { ther to form a whole, with empha- } \\
\text { sis on creating a new meaning or } \\
\text { structure. }\end{array}$ & $\begin{array}{l}\text { - Curate a digital exhibit or program a series for ex- } \\
\text { hibition or broadcast with historical or theoretical } \\
\text { framework for understanding. }\end{array}$ \\
\hline
\end{tabular}

act or as part of the decision process must consider the importance of psychomotor learning. Fields as diverse as medicine and nursing, engineering, the physical sciences, art and the performing arts, and architecture have integrated psychomotor learning objectives and competencies in their curriculum design, because these fields require professionals with highly developed hand and sensory skills. Cognitive learning often provides the context and theoretical foundations for approaching particular tasks or problems, affective learning empowers the professional to work efficiently, effectively, and respectfully with colleagues and patrons, but psychomotor learning provides the final leg of the stool for those who have responsibilities to care for and make accessible heritage objects and collections.

Several taxonomies have been developed to describe the levels of psychomotor learning [56-58], however, the one created by Dave is most useful for the development of professional competencies in information fields where motor skills and sensory input is important.

Summarized in Table 3, Dave's hierarchy of psychomotor learning levels takes students from imitation through manipulation, precision, articulation, and finally, naturalization. 
Table 2

Affective domain of Bloom's taxonomy, as summarized by Clark [61,62]

\begin{tabular}{|c|c|c|}
\hline Level & Definition & Selected examples \\
\hline $\begin{array}{l}\text { Receiving } \\
\text { phenomena }\end{array}$ & $\begin{array}{l}\text { Awareness of the phenomenon, will- } \\
\text { ingness to listen, and selected atten- } \\
\text { tion where appropriate. }\end{array}$ & $\begin{array}{l}\text { - Learner listens to others with respect in } \\
\text { the classroom, at work, and in social sit- } \\
\text { uations where interaction with colleagues } \\
\text { takes place. } \\
\text { - Acknowledges instructions and duties of } \\
\text { their position. }\end{array}$ \\
\hline $\begin{array}{l}\text { Responding to } \\
\text { phenomena }\end{array}$ & $\begin{array}{l}\text { Active participation on the part of the } \\
\text { learners. Attend to and react to a par- } \\
\text { ticular phenomenon. Learning out- } \\
\text { comes may emphasize compliance in } \\
\text { responding, willingness to respond, } \\
\text { or motivation to respond. }\end{array}$ & $\begin{array}{l}\text { - Learner reacts in a timely manner to re- } \\
\text { quests for information and input. } \\
\text { - Learner is motivated to perform job duties } \\
\text { at a high level. } \\
\text { - Learner responds positively to constructive } \\
\text { criticism about their performance. }\end{array}$ \\
\hline Valuing & $\begin{array}{l}\text { Recognizing the worth or value a } \\
\text { person attaches to a particular ob- } \\
\text { ject. Based on the internalization of } \\
\text { a set of specified values; external } \\
\text { clues to these values are found in the } \\
\text { learner's behavior and actions. }\end{array}$ & $\begin{array}{l}\text { - Learner shows sensitivity to the needs of } \\
\text { others (colleagues, supervisors, clients/pat- } \\
\text { rons, etc.) through patience, empathy, and } \\
\text { other supportive behavior. } \\
\text { - Learner embraces collaboration as a foun- } \\
\text { dational value by striving to work harmo- } \\
\text { niously with others. }\end{array}$ \\
\hline Organizing & $\begin{array}{l}\text { Learner organizes values into prior- } \\
\text { ities by contrasting different values, } \\
\text { resolving conflicts between them, } \\
\text { and creating a unique value system. } \\
\text { Emphasis is on comparing, relating, } \\
\text { and synthesizing values. }\end{array}$ & $\begin{array}{l}\text { - Learner's attitudes reflect the commonly } \\
\text { accepted values of the profession (as ex- } \\
\text { pressed via its code of ethics or other guid- } \\
\text { ing principles). }\end{array}$ \\
\hline $\begin{array}{l}\text { Internalization } \\
\text { of Values (char- } \\
\text { acterization) }\end{array}$ & $\begin{array}{l}\text { Learner has a value system that con- } \\
\text { trols their behavior. Their behavior } \\
\text { is pervasive, consistent, predictable, } \\
\text { and ethical. }\end{array}$ & $\begin{array}{l}\text { - Learner matures as a professional through } \\
\text { ethical performance of work duties, and in- } \\
\text { teractions with others in the organization } \\
\text { and the field. }\end{array}$ \\
\hline
\end{tabular}

Psychomotor skills are sometimes underplayed in graduate education or described as "training" (to distinguish it from graduate education), with the assumption that students will gain many of these necessary skills in their first professional position. Yet, employers often consider these skills to be essential for obtaining entry-level positions. Thus, in the AV archiving field it is essential that students make initial steps toward mastery of these skills to be successful in obtaining their first professional position.

Psychomotor skills/competencies are usually acquired through an instructional process that progresses from imitation to practice to habit, which means that students need time for such skills to become second nature. Internships have their place in facilitating this process, but educators also need to provide students with other opportunities to begin their journey on the continuum from beginner to expert by integrating psychomotor learning activities throughout their programs. By articulating psychomotor competencies in professional competency sets and educational guidelines, audiovisual archiving can create a framework that is holistic and recognizes the central importance of such skills in the profession. For those programs that are pri- 
Table 3

Psychomotor domain developed by Dave, as summarized by Huitt, with examples

\begin{tabular}{|c|c|c|}
\hline Level & $\begin{array}{l}\text { Definition } \\
\text { (from Simpson) [58] }\end{array}$ & Audiovisual archiving in situ examples \\
\hline Imitation & $\begin{array}{l}\text { Observe a skill and attempt } \\
\text { to repeat it, or, see a fin- } \\
\text { ished product and attempt } \\
\text { to replicate it while attend- } \\
\text { ing to an exemplar. }\end{array}$ & $\begin{array}{l}\text { - Watch an expert splice the ends of two pieces of film } \\
\text { together, and then attempt to replicate that splice with } \\
\text { the same quality (in terms of alignment of edges, appli- } \\
\text { cation of tape or adhesive, and strength of join). } \\
\text { - Observe an expert use equipment such as reel to reel } \\
\text { tape player, a flatbed film viewer, or a digitization work- } \\
\text { station and be able to repeat the task using that equip- } \\
\text { ment and without causing harm to the materials. }\end{array}$ \\
\hline Manipulation & $\begin{array}{l}\text { Perform the skill or pro- } \\
\text { duct the product in a rec- } \\
\text { ognizable fashion by foll- } \\
\text { owing general instructions } \\
\text { rather than observation. }\end{array}$ & $\begin{array}{l}\text { - Identify deterioration in audiovisual material based on } \\
\text { knowledge learned through classroom learning, obser- } \\
\text { vation of a professional, and with appropriate supervi- } \\
\text { sion. } \\
\text { - Prepare an audiovisual item for transfer to digital form } \\
\text { by following laboratory instructions for cleaning of the } \\
\text { item, description of the item's key characteristics (e.g., } \\
\text { format, length, gauge, speed, etc.), and other laboratory } \\
\text { requirements for prepping. }\end{array}$ \\
\hline Precision & $\begin{array}{l}\text { Independently perform the } \\
\text { skill or produce the prod- } \\
\text { uct, with accuracy, propor- } \\
\text { tion, and exactness; at an } \\
\text { expert level. }\end{array}$ & $\begin{array}{l}\text { - Independently prepare objects for exhibition through } \\
\text { thorough inspection, written documentation, and fol- } \\
\text { lowing institutional guidelines for protection of the item } \\
\text { from harm during exhibition. }\end{array}$ \\
\hline Articulation & $\begin{array}{l}\text { Modify the skill or pro- } \\
\text { duce the product to fit new } \\
\text { situations; combine more } \\
\text { than one skill in sequence } \\
\text { with harmony and consis- } \\
\text { tency. }\end{array}$ & $\begin{array}{l}\text { - Adjust inspection, preservation, digitization, or descrip- } \\
\text { tion workflows or techniques as needed to deal with } \\
\text { particular problems presented by the audiovisual ob- } \\
\text { jects/collections. }\end{array}$ \\
\hline Naturalization & $\begin{array}{l}\text { Completion of one or more } \\
\text { skills with ease and mak- } \\
\text { ing the skill automatic } \\
\text { with limited physical or } \\
\text { mental exertion. }\end{array}$ & $\begin{array}{l}\text { - Complete a complex sequence of steps to prepare and } \\
\text { digitize audiovisual items, which follows standards, } \\
\text { best practices, and institutional guidelines for various } \\
\text { activities that are part of the process. }\end{array}$ \\
\hline
\end{tabular}

marily online, it is essential to create opportunities for students to develop these skills via practica or short-term "boot camps" that can instill the basics. Faculty advisors and instructors should also guide students to additional educational opportunities beyond the virtual classroom, where appropriate and feasible.

It is also critical that the field recognize and articulate varying skills levels, not just in the psychomotor domain, but in the other domains as well. Educators will find such differentiation helpful in designing coursework and continuing education opportunities. Individuals come into the profession with varying levels of preparation and experience, and having a clear sequence of skill levels and associated activities can help them accurately assess their need for additional education and experience. A number of competency sets feature this categorization of competencies at different levels of expertise. As an example, the AIC competency set Requisite 
Competencies for Conservation Technicians and Collections Care Specialists [37] defines levels of competence and associates particular tasks or activities (or responsibility for decision-making) with increasing competence in that task or activity (see the example below).

- Collection Housing [competency]

* Task level I: performs basic housing techniques (e.g., placing objects in specified, prefabricated enclosures) and makes simple custom-fit enclosures.

* Task level II: designs and makes complex, custom-fit enclosures with supplied materials.

* Task level III: determines and/or proposes appropriate housing materials and techniques, as well as equipment and supplies needed; drafts designs and constructs appropriate enclosures and supports.

* Conservator level: determines appropriate housing materials and techniques; determines and reviews designs and oversees fabrication of enclosures and supports; evaluates enclosures, storage furniture, and the storage environment.

As the above example shows, as the person becomes more competent, that person will have more supervisory and decision-making responsibilities. This example also shows how cognitive, affective, and psychomotor skills often must be combined together in higher level activities - the higher levels of skill certainly require more advanced knowledge of materials, storage environments, as well as design expertise.

\subsection{Conclusions and future directions}

The above discussion lays out the need for a more formalized expression of the knowledge base and skills required for audiovisual archivists in the current era. The time is ripe to develop a framework of competencies that is holistic in nature, encompassing and integrating expertise that resides in the mind and body of the professional. It is a logical next step for the audiovisual archiving profession in the progression toward professionalization, and it would also present evidence for how this field differentiates itself from other fields in the information profession; while convergence is often encouraged in the cultural heritage and information professions, it is also important to respect the differences and unique knowledge residing in these communities of practice.

The next steps to take in creating a competency framework will be to align current research on competencies being accomplished by scholars and educators in the audiovisual archiving field. The author of this study belongs to a research team, the Audiovisual Competency Framework Working Group [59], whose members have been working on generating competencies from analysis of course syllabi and job advertisements, and looking at high-level competencies across allied fields to identify similarities among the cultural heritage and information professions. The alignment of these data sources will result in a preliminary framework, which will then be 
validated through surveys of stakeholders, including instructors currently teaching in the audiovisual archiving area, employers (i.e., working audiovisual specialists in libraries, archives, museum, and other noncommercial and commercial environments such as laboratories and corporate archives), and current and recently graduated students in the field. Through consultation with the members of the community, the working group aims to produce an integrated educational framework that accurately reflects the diverse knowledge and skill set of the field. It is hoped that this framework will be useable by stakeholders for a variety of uses and will also inspire educators to consider ways of incorporating all domains of learning in their teaching.

\section{Acknowledgments}

The author would like to acknowledge the support and wisdom of members of the Audiovisual Competency Framework Working Group and members of the Association of Moving Image Archivists, particularly the Continuing Education Advisory Task Force, for their feedback and support for this project.

\section{References}

[1] Cox RJ. Graduate archival education in the United States: A personal reflection about its past and future. Journal of Contemporary Archival Studies [Internet] 2015; 2. Available from: http:// elischolar.library.yale.edu/jcas/vol2/iss1/3.

[2] Staresina E. Audiovisual archiving and the world of tomorrow: Explorations into accreditation and certification. The Moving Image 2006; 6(1): 102-10.

[3] Linn M. Not waiting for Godot: The history of the Academy of Certified Archivists and the professionalization of the archival field. The American Archivist 2015; 78(1): 96-132.

[4] Association AL. Guidelines for choosing a master's program in library and information studies. Available from: http://www.ala.org/educationcareers/accreditedprograms/guidelines-choosingmasters-program-library-and-information-studies.

[5] Winter MF. The professionalization of librarianship. University of Illinois, Graduate School of Library and Information Science, occasional papers 1983; (160): 1-46.

[6] Society of American Archivists. Guidelines for Graduate Program in Archival Studies. Chicago: Society of American Archivists; 2016. Available from: https://www2.archivists.org/prof-education/ graduate/gpas.

[7] Archivists AoC. Handbook for Archival Certification. Albany, NY: ACA; 2012.

[8] Bates MJ. The information professions: Knowledge, memory, heritage. Information Research [Internet] 2015; 20(1). Available from: http://InformationR.net/ir/20-1/paper655.html.

[9] Williamson CC. Training for Library Service: A Report Prepared for the Carnegie Corporation of New York. New York: Carnegie Corporation; 1923.

[10] Asheim LE. Librarians as professionals. Library Trends. 1979; 27(3): 225-57.

[11] Abbott A. The System of Professions: An Essay on the Division of Expert Labor. Chicago: University of Chicago Press; 1988.

[12] Turrini JM. The historical profession and archives education. Perspectives on History [Internet] 2007. Available from: https://www.historians.org/publications-and-directories/perspectiveson-history/may-2007/the-historical-profession-and-archival-education.

[13] Hamburger S. Archival certification - necessiry or nicety? Society of American Archivists Research Forum (2013); June 2014. 
[14] Irons Walch V. Part 3. A*CENSUS: A closer look. The American Archivist 2006; 69(2): 328-405.

[15] Gutsche B, Hough B. Competency index for the library field: Compiled by WebJunction. Dublin, Ohio: OCLC; 2014.

[16] Ashcroft L. Developing competencies, critical analysis and personal transferable skills in future information professionals. Library Review 2004; 53(2): 82-8.

[17] Griffiths J-M. The changing role of librarians: Managing new technologies in libraries. In: Library and Information Services in Astronomy II (LISA-II). Murtagh F, Grothkopf U, Albrecht M. editors. Garching, Germany: Elsevier; May 10-12 1995. p. 127-35.

[18] Giesecke J, McNeil B. Core competencies and the learning organization. Library Administration and Management 1999; 13(3): 158-66.

[19] Association for Information Science and Technology. ASIST educational guidelines: American Society of Information Science and Technology; 2001. Available from: http://www.asis.org/Board/ educational_guidelines.html.

[20] Association for Information Science and Technology. ASIS\&T white paper: Accreditation of Programs for the Education of Information Professionals. 2007.

[21] American Library Association. Core competences of librarianship. Chicago: American Library Association; 2009. Available from: http://www.ala.org/educationcareers/sites/ala.org.educationcar eers/files/content/careers/corecomp/corecompetences/finalcorecompstat09.pdf.

[22] Association for Library Collections and Technical Services. Core competencies for cataloging and metadata professional librarians: ALCTS; 2017. Available from: https://alair.ala.org/bitstream/han dle/11213/7853/Core\%20Competencies\%20Cataloging\%20Metadata\%20Professional.pdf?sequen ce $=1 \&$ is Allowed $=y$.

[23] Young Adult Library Services Association. Teen services competencies for library staff: YALSA; 2017. Available from: http://www.ala.org/educationcareers/sites/ala.org.educationcareers/files/cont ent/resourcesforprogramadministrators/YALSA_TeenCompetencies_web_Final_2018.pdf.

[24] American Association of School Librarians. ALA/AASL standards for initial preparation of school librarians: ALA/AASL; 2010. Available from: http://www.ala.org/aasl/sites/ala.org.aasl/files/cont ent/aasleducation/schoollibrary/2010_standards_with_rubrics_and_statements_1-31-11.pdf.

[25] Art Libraries Society of North America. ARLIS/NA core competencies for art information professionals: ARLIS/NA; 2017. Available from: https://www.arlisna.org/images/researchreports/arlisna corecomps.pdf.

[26] North American Serials Interest Group. Core competencies for print serials management: NASIG; 2015. Available from: http://www.nasig.org/site_page.cfm?pk_association_webpage_menu=310 \&pk_association_webpage $=8576$.

[27] North American Serials Interest Group. NASIG core competencies for electronic resources librarians: NASIG; 2016. Available from: http://www.nasig.org/site_page.cfm?pk_association_webpage _menu=310\&pk_association_webpage $=7802$.

[28] Medical Library Association. Professional competencies for health sciences librarians: MLA; 2007. Available from: http://www.mlanet.org/education/policy/.

[29] American Association of Law Libraries. Competencies of law librarianship: AALL; 2010. Available from: https://www.aallnet.org/about-us/what-we-do/policies/public-policies/competencies-oflaw-librarianship/.

[30] Ammons-Stephens S, Cole HJ, Jenkins-Gibbs K, Riehle CF, Weare WH, Jr. Developing core leadership competencies for the library profession. Library Leadership and Management 2009; 23(2): 63-74.

[31] Hunter D. Core competencies and music librarians. NP: Library School Liaison Subcommittee, Music Library Association; 2002

[32] North American Serials Interest Group. NASIG core competencies for scholarly communication librarians: NASIG; 2017. Available from: http://www.nasig.org/site_page.cfm?pk_association_web page_menu $=310 \&$ pk_association_webpage $=9435$.

[33] Association of College and Research Libraries. Guidelines: competencies for special collections professionals: ACRL/ALA; 2017. Available from: http://www.ala.org/acrl/standards/ comp4specollect. 
[34] Special Libraries Association. Competencies for information professionals: SLA; 2016. Available from: http://www.sla.org/about-sla/competencies/.

[35] Iyer H. Core competencies for visual resources management: An IMLS funded research project at the University at Albany, SUNY. SUNY Albany; 2007.

[36] American Institute for Conservation of Historic and Artistic Works. Defining the Conservator: Essential Competencies. Washington, DC: AIC; 2003.

[37] Collections Care Task Force of the American Institute for Conservation of Historic and Artistic Works. Requisite competencies for conservation technicians and collections care specialists. Washington, DC: AIC; 2005.

[38] Slide A. Nitrate Won't Wait: A History of Film Preservation in the United States. Jefferson, NC: McFarland; 1992.

[39] Houston P. Keepers of the Frame: The Film Archives. London: British Film Institute; 1994.

[40] Gracy KF. Film preservation: Competing Definitions of Value, Use, and Practice. Chicago: Society of American Archivists; 2007.

[41] Frick C. Saving Cinema: The Politics of Preservation. Oxford: Oxford University Press; 2011.

[42] Harrison HP. Curriculum Development for the Training of Personnel in Moving Image and Recourded Sound Archives: Report of the Working Party, January 1990. Paris: UNESCO; 1990.

[43] Edmondson R. Audiovisual Archiving: Philosophy and Principles. Paris: UNESCO; 2016.

[44] Wagenaar R. Competences and learning outcomes: A panacea for understanding the (new) role of higher education? Tuning Journal for Higher Education 2014; 1(2): 279-302.

[45] McClelland DC. Testing for competence rather than for "intelligence". American Psychologist 1973; 28(1): 1-14.

[46] Hannaford C. Smart Moves: Why Learning Is Not All in Your Head. Salt Lake City, UT: Great River Books; 2005.

[47] Ahmed K, Miskovic D, Darzi A, Athanasiou T, Hanna GB. Observational tools for assessment of procedural skills: A systematic review. American Journal of Surgery 2011; 202: 469-80.

[48] Reznick RK. Teaching and testing technical skills. American Journal of Surgery 1993; 165: 358-61.

[49] Salyers VL. Teaching psychomotor skills to beginning nursing students using a web-enhanced approach: A quasi-experimental study. International Journal of Nursing Education Scholarship 2007; 4(1): $1-12$.

[50] Aldridge MD. Nursing students' perceptions of learning psychomotor skills: A literature review. Teaching and Learning in Nursing 2017; 12: 21-7.

[51] Isik B, Kaya $\mathrm{H}$. The effect of simulation software on learning of psychomotor skills and anxiety level in nursing education. Procedia - Social and Behavioral Sciences 2014; 116: 3864-8.

[52] Oermann MH, Morgan B. Framework for teaching psychomotor and procedural skills in nursing. Journal of Continuing Education in Nursing 2016; 47(6): 278-82.

[53] Calhoun JG. Development of a core competency model for the master of public health degree. American Journal of Public Health 2008; 98(9): 1598-607.

[54] Bloom BS. Taxonomy of Educational Objectives, Handbook I: The Cognitive Domain. New York: David McKay Co.; 1956

[55] Anderson LW, Krathwohl DR, Airasian PW, Cruikshank KA, Mayer RE, Pintrich PR, et al. A Taxonomy for Learning, Teaching, and Assessing: A Revision of Bloom's Taxonomy of Educational Objectives. New York: Pearson, Allyn and Bacon; 2001.

[56] Dave R. Psychomotor Domain. Berlin: International Conference of Educational Testing; 1967.

[57] Harrow AJ. A Taxonomy of the Psychomotor Domain: A Guide for Developing Behavioral Objectives. New York: D. McKay Co.; 1972.

[58] Simpson EJ. The Classification of Educational Objectives, Psychomotor Domain. Urbana, IL: University of Illinois; 1966.

[59] AV Competency Framework Working Group. Welcome to the Workspace for the AV Competency Framework Working Group! 2018. Available from: https://sites.google.com/a/kent.edu/ audiovisual-competency-framework-working-group/.

[60] Clark D. Bloom's taxonomy of learning domains 2015. [updated January 12, 2015]. Available from: http://www.nwlink.com/ donclark/hrd/bloom.html. 
[61] Krathwohl DR, Bloom BS, Masia BB. Taxonomy of Educational Objectives, the Classification of Educational Goals. Handbook II, Affective Domain. New York: David McKay Co.; 1973.

[62] Clark D. Bloom's Taxonomy: The Affective Domain 2015. [updated January 12, 2015]. Available from: http://www.nwlink.com/ donclark/hrd/Bloom/affective_domain.html. 